\title{
Structural state of chernozems of Forest-Steppe zone at agrogenic impact
}

\author{
Demydenko O. \\ Cherkasy State Agricultural Research Station of National Institute of Agriculture of NAAS \\ 13 Dokuchaieva Str., Holodnianske village, Smila region, Cherkasy oblast, 20731, Ukraine \\ e-mail: smilachiapv@ukr.net \\ ORCID: 0000000253341154
}

Goal. To determine the main regularities of the transformation of the structural state of chernozems of the Forest-Steppe zone under conditions of long-term agrogene transformation. Methods. Field and laboratory experiment (dry structural dispersion of soil). Statistical-analytical method of factor analysis (principal component method), cluster analysis, non-parametric methods of analysis of the obtained data of the structural state. Results. They fixed the following regularities at the increase of agro- and technogenic load on the chernozem: fractions of structural parts in size of $>7 \mathrm{~mm}$ were formed of the greater degree, and to a lesser extent there were formed fractions in size of $<0.25 \mathrm{~mm}$. At the same time, they determined a decrease in the number of the most valuable in agronomic understanding of fraction in size of $3.0-0.5 \mathrm{~mm}$. That process is much more evident at the systematic plowing. The use of subsurface cultivation contributed to the restoration of soil structure and the formation of separate intermediate fractions in size of $7-5 \mathrm{~mm}$ and $5-3$ $\mathrm{mm}$, and a slight increase in the number of fractions in size of $3-0.5 \mathrm{~mm}$. It also promoted the destruction of big fractions, with a gradual increase in the number of more valuable fractions $(7-5 \mathrm{~mm}$ and $5-3 \mathrm{~mm})$, which led to a minor increase in the density structure of the $0-30 \mathrm{~cm}$ soil layer in the first $3-5$ years. Loosening started at the increase of the content of structural units in size of $5-3 \mathrm{~mm}$ with the further consolidation of the soil structure around the formation of the structural units of size $3-0.5 \mathrm{~mm}$, which caused the decrease in the content of structural units in size of $<0.25 \mathrm{~mm}$. Conclusions. So, the size fraction of $10-7 \mathrm{~mm}$ is an important characteristic of cultivated chernozems of Forest-Steppe, which can determine the formation of the chernozem in agrocenoses under the influence of agrogenic load. General regularity was fixed: regardless of the status of the chernozem the share of units in size of $3-0.5 \mathrm{~mm}$ in the amount of agronomically valuable $(7-0.25 \mathrm{~mm})$ units, regardless of their number, was $51-54 \%$, and increased agrogenic load accelerated the formation of big fractions $(>7 \mathrm{~mm})$ up to $30 \%$, of agronomically invaluable units - to $35.6 \%$, the share of structural units in size of $<0.25 \mathrm{~mm}$ made $6-10 \%$.

Key words: cluster analysis, factor analysis, idle field, plowing, surface cultivation, density of soil.

DOI: https://doi.org/10.31073/agrovisnyk202004-01

The parameters of the physical structure belong to the main fast-changing properties of black earth. Already in the first years after plowing, there is a dramatic change in the structural state, density of structure and water-physical properties of the black earth [1]. The conducted researches made it possible to establish norms of changes of physical properties of arable chernozems and limit values of parameters of their indicators, to predict losses of productivity of crops at deterioration of a structural condition and consolidation [2-4]. The optimal equilibrium density for the main subtypes of black earth is $1.0-1.25 \mathrm{~g} / \mathrm{cm}^{3}$ with agronomically valuable aggregates $>70 \%$. With such agro-physical parameters, minimal technologies of their basic processing can be used [9]. According to numerous studies it has been found that the productivity of crops decreases with numerous passes of heavy machinery [5-6]. The variation of the physical properties of the arable layer of the black soil of the forest-steppe zone is connected not only with genetic traits, but also to a large extent with the duration and nature of their use, as well as the level of crop culture in general [7-8]. To optimize the physical properties (structural state), it is necessary to take measures to create a positive humus balance, and after reaching the optimum - to maintain it at a deficit-free level [9]. The degradation of the physical state of the black earths means a steady deterioration of their physical properties, first of all, the structural state and density of folding, which leads to the deterioration of water, air, nutritional regimes and ultimately - to a decrease in fertility [10].

In agrogenic chernozems, with the deterioration of the structural state, the equilibrium density of the structure increases significantly compared with the natural chernozems-analogues, a new phenomenon occurs - the consolidation of structural aggregates and the decrease of the intraaggregation rate, which impairs the conditions of water-mineral nutrition. Structural and compacted chernozems, even under moderate loads, may have horizontally elongated macrospars characteristic of shallow or sub-shallow soil structure, which further changes the agrophysical properties of the arable layer [12-13]. According to V.V. Medvedev [14-15], reducing the depth and number of cultivation or abandoning their cultivation, a high crop of agriculture and organic fertilizers or leaving the crop residues on the field gradually improves the structural 
composition of the black soil in intensive cultivation, and during the fieldless cultivation the process of reproduction of their structure becomes active forms.

Investigation of the parameters and orientation of the transformation of the structural state of the black earth, which change under the conditions of modern long-term agrogenic influence, is important for the scientific substantiation of the process of agrophysical degradation. The solution of this issue is relevant for the production needs of soil cultivation, establishment of their bioproductivity and development of measures to prevent further agrophysical degradation of black soil in the agrocenoses of the Left Bank Forest Steppe.

The novelty of the conducted research lies in the fact that using modern methods of statistical analysis of air-dry sifting data in the study of the structural state of black earths during agrogenic loading, it is possible to reveal a deeper content of the orientation of structure formation. It has also been found that with the increase of the agrogenic influence, there is an active imbalance of the soil structure, while the mechanism of strengthening the stability of the structural state in the direction of holding the branches and the virgin soil is reproduced by reducing the intensity of the agrogenic influence.

The purpose of the research is to find out the basic regularities of transformation of the structural state of the chernozem of the forest-steppe zone under the conditions of long-term agrogenic transformation.

Materials and methods of research. The methods of field and laboratory experiment (dry structural soil dispersion), statistical-analytical method, factor analysis method (principal component method), cluster analysis, nonparametric methods of analysis of the obtained structural state data were applied.

Materials and methods of research. The methods of field and laboratory experiment (dry structural soil dispersion), statistical-analytical method, factor analysis method (principal component method), cluster analysis, nonparametric methods of analysis of the obtained structural state data were applied.

In 1990-1996 the long-term influence of soil cultivation on the restoration of the structural state of chernozems typical in the Agrocenoses of the Eastern Forest-Steppe of the physical-geographical zone of Ukraine in the South Poltava Agro-ecological Region was studied [17]. The soil cover is represented by chernozems typical humus (5.55-5.65\%). According to the content of physical clay (FG) and physical sand $(\mathrm{AF})$, black soil can be counted as light clay: $\mathrm{FG}=62.9-64 \%$; $\mathrm{AF}=35-37.1 \%$. The structural condition of the field was investigated, where for more than 80 years various plowing plowing with application of $8 \mathrm{t} / \mathrm{ha}$ of manure + N90P90K80 was performed, the variant of plowing for 10 years - in the experiment with application of 10-12 t/ha of manure + N90P90K80. In the field of 10-axis crop rotation was carried out various-depth tillage with application of 10-12 t/ha of manure + N90P90K80. To expand the general model of the structural state, the study [16] of plowing variants of the "Michael's virgin" and "Rogan hospital" was used.

From 2001 to 2018, studies were conducted in the Eastern Forest-Steppe of the Central-Left BankPridneprovsky Agro-ecological Area. The experiment is based on the black earths of typical low-humus lightloamy silt-dusty ones. Structural index (PS) is $25-38 \%$. The ratio of AF to FG is $1.76-2.52$, which is 3.2 times higher compared to the typical medium-humic loamy soil. The potential aggregation factor (FPA) is $0.25-$ 0.27 , which is $2.78-2.96$ times lower than in the black earths of typical medium humus clayey ones. The solid phase density of practically studied black earths is the same and varies in the soil layer $0-20 \mathrm{~cm}$ from $2.62 \mathrm{~g} / \mathrm{cm}^{3}$ to $2.65 \mathrm{~g} / \mathrm{cm}^{3}$.

Investigated the structural condition of long-term plowing (more than 55 years) in a stationary experiment, where up to 1990, $8 \mathrm{t} /$ ha of manure + N60P60K50 was introduced, and after manure was replaced with byproducts of 6-8 $\mathrm{t} / \mathrm{ha}$. Non-shelf multi-depth and surface tillage with a similar fertilizer system as for plowing. The average distribution of chernozems in the state of fallow and virgin soil over the 10 to 100 years of the eastern forest-steppe of Ukraine is taken as the standard of distribution.

The analysis of the structural composition was carried out in the soil layer $0-40 \mathrm{~cm}$. Physical parameters were investigated: density of the solid phase of the soil by pycnometric method (DSTU 4745: 2007); soil folding density (DSTU ISO 11272-2001); dry sieving according to the method of MI Savvinov (DSTU 4744: 2007) [31]. The structural condition was studied together with the determination of the density of the structure. The content of the total humus - according to IV Tyurin in modification MV Simakov (DSTU 4289: 2004). A fractal estimation of the series of structural individual distributions was carried out by K.G. Moses [18] and B.V. Kiselyov [19]. Interpretation of structural state data was carried out by cluster and factor analysis methods [20].

Research results. The results of air-dry sieving and the distribution of structural individuals by the size of the cultivated chernozems in the soil layer $0-30 \mathrm{~cm}$ are presented in Fig. 1. During systematic plowing with different lengths, the number of agronomically invaluable structural units increases up to $20-25 \%(>7 \mathrm{~mm}$ ) and $10,2-17,1 \%(<0,25 \mathrm{~mm})$. At the same time there is a decrease in the content of structural units $3-0.5 \mathrm{~mm}$ to $31.1-35.3 \%$ or $1.29-1.46$ times relative to the translucent and virgin analogues of the chernozem. 


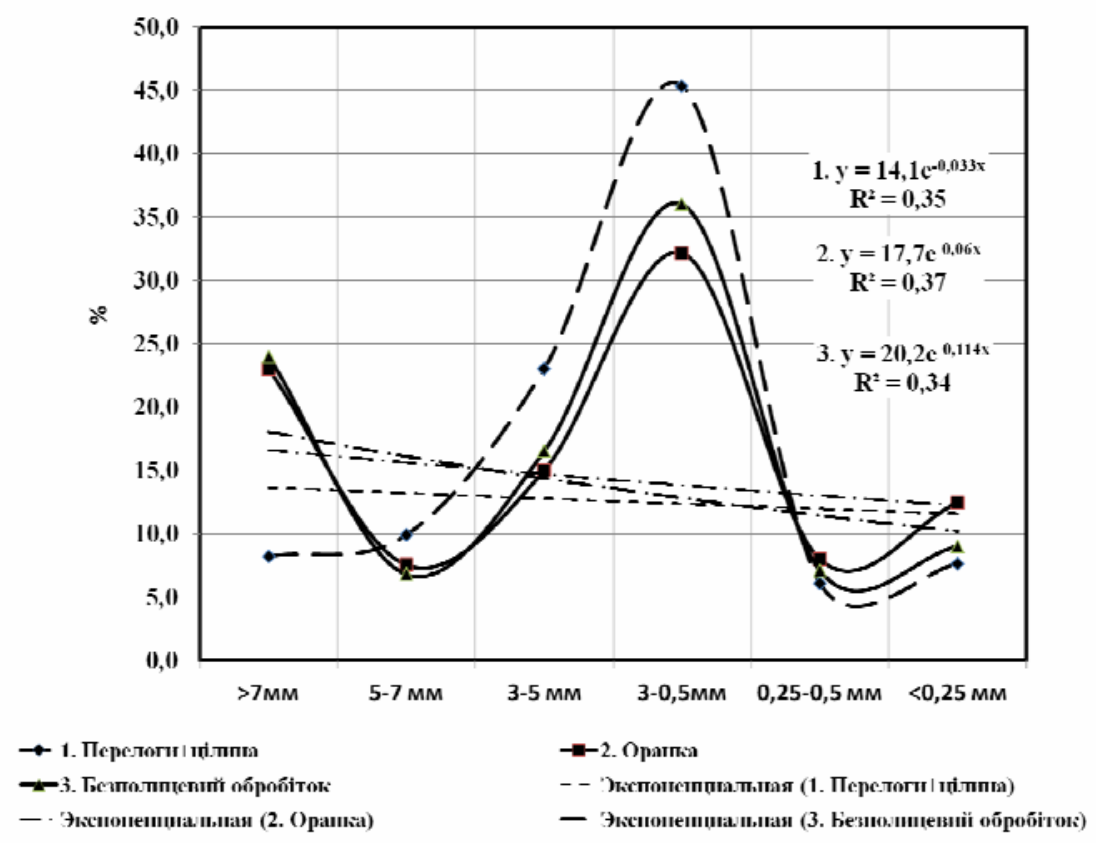

Fig. 1. Redistribution of structural features of black earths of agrogenic loading and postdegradation retention

Similarly, there is a redistribution of structural units for unmanned processing. Content of individual sizes> $7 \mathrm{~mm}$ reaches $30 \%$ and $<0.25 \mathrm{~mm}$ does not exceed $15 \%$. The number of individual $3-0.5 \mathrm{~mm}$ exceeds $35 \%$ on average. During the systematic plowing, the number of individuals $5-7 \mathrm{~mm}$ varies in a wider range of values (4.4-10.7\%), while for non-polishing treatment, the individuals of this size are $4.3-8.0 \%$. In the case of shelf-free cultivation, there is an increase in the content of structural fragments of $5-3 \mathrm{~mm}$ in size and a steady decrease in the contents of the fragments of $0.5-0.25 \mathrm{~mm}$, that is, the consolidation of the contents of structural fragments around the fraction of 3-0.5 mm as for the retention of virgin and false analogues (Fig. 1).

Determination of fractal dimension (D) and Hearst index $(\mathrm{H})$ of distribution of structural individuals by size (Table 1) at post-orogenic content of black earths and in the state of intensive cultivation showed that under natural retention the indicators $D$ and $H$ characterize the state of the soil system as stable $(D=1.01-1.40)$, and the Hearst index acquires values that correspond to the persistent state $(0<\mathrm{H}<0.5)$ of the soil structure or trend-stable series. The values of $\mathrm{D}$ and $\mathrm{H}$ in the amplitude range and the typical interval of values correspond to the persistence of the series of distribution of structural individuals with a coefficient of variation of 12.9 and $6.48 \%$, respectively. The degree of correlation (C) in the distribution of size divisions has a high level $(C=0.65-0.95)$, and the typical interval value $C=0.87-0.95$, which indicates the established natural order of the distribution of the individual, which will persist in the future, that is, the soil structure of the chernozem in the post-porogenic state is in the quasi-non-equilibrium state.

1. Fractal estimation of the series of distribution of structural features of chernozems of postagrogenic retention and aerogenic loading

\begin{tabular}{|c|c|c|c|c|c|c|c|}
\hline \multirow[b]{2}{*}{$\begin{array}{l}\text { Indicators } \\
\text { fractal } \\
\text { evaluation }\end{array}$} & \multirow[b]{2}{*}{$\begin{array}{l}\frac{\Phi}{\mathscr{D}} \\
\frac{\pi}{\Phi} \\
\stackrel{\mathbb{\alpha}}{\varangle}\end{array}$} & \multirow[b]{2}{*}{$\frac{\frac{c}{\pi}}{\frac{\pi}{0}}$} & \multicolumn{2}{|c|}{$\begin{array}{l}\text { Amplitude range } \\
(\Delta=\text { max-min): }\end{array}$} & \multicolumn{2}{|c|}{$\begin{array}{c}\text { Normalized span } \\
\Delta=L 0.75-0.25\end{array}$} & \multirow{2}{*}{ 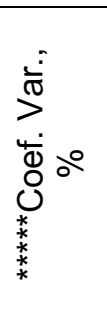 } \\
\hline & & & $\min$ & $\max$ & ${ }^{* * * *} \mathrm{~L}_{0,25}$ & ${ }^{* * * *} \mathrm{~L}_{0,75}$ & \\
\hline \multicolumn{8}{|c|}{ Postagrogenic loading of black earth } \\
\hline $\mathrm{D}$ & 1,01 & 1,03 & 0,76 & 1,14 & 0,97 & 1,05 & 12,9 \\
\hline $\mathrm{H}=2-\mathrm{D}$ & 0,97 & 0,97 & 0,86 & 1,03 & 0,95 & 1,03 & 6,48 \\
\hline $\mathrm{C}=2^{2 \mathrm{H}-1}-1$ & 0,92 & 0,92 & 0,65 & 0,95 & 0,87 & 0,95 & - \\
\hline \multicolumn{8}{|c|}{ The general model of agrogenic loading of black earths } \\
\hline${ }^{*} \mathrm{D}$ & 1,26 & 1,27 & 1,04 & 1,48 & 1,15 & 1,32 & 9,50 \\
\hline
\end{tabular}




\begin{tabular}{|l|l|l|l|l|l|l|c|}
\hline${ }^{* *} \mathrm{H}=2-\mathrm{D}$ & 0,75 & 0,73 & 0,55 & 0,96 & 0,68 & 0,85 & \begin{tabular}{c}
15,7 \\
\hline${ }^{* *} \mathrm{C}=2^{2 \mathrm{H}-1}-1$
\end{tabular} \\
\hline
\end{tabular}

Notes: ${ }^{*}$ Fractal dimension - $\mathrm{D} ;{ }^{* *}$ Hearst indicator $-\mathrm{H} ;{ }^{* * *}$ Autocorrelation in a series of distribution - C; ${ }^{* * * *} \mathrm{~L} 0,25$ - lower quantile; L0,75 is the top quantile; ${ }^{* * * *}$ Coef. Var., \% Is the coefficient of variation.

In the cultivated chernozem, the values of $\mathrm{D}$ and $\mathrm{H}$ are within the values of the persistent state of distribution of structural individuals, but the value of $\mathrm{D}$ increases 1.25 times and $\mathrm{H}$ decreases 1.29 times, tilting the soil structure to the lower limit of stability $(D=1.40)$ and to the "noisy" number of structural separation distributions with a less pronounced trend $(H=0.5)$, characterized by a minimum lower typical and significant (at $10 \%$ level) value of $\mathrm{N}$. The coefficient of variation of $\mathrm{D}$ and $\mathrm{H}$ in the general model was $9.5 \%$ and $15.7 \%$, and for plowing -10.4 and $17.9 \%$, while for non-polishing treatment wea $8.0-12.9 \%$, which is a more stable distribution. The degree of correlation between groups of individuals (C) in cultivated chernozems was lower compared to natural analogues: it was $8.5-42.3 \%$ against $75.7-90.0 \%$, which indicates a significant imbalance of the structural state of cultivated chernozems.

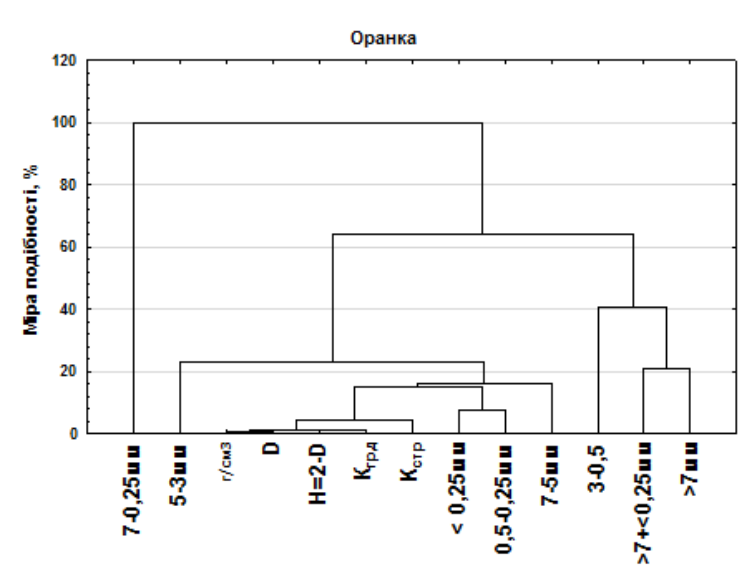

A

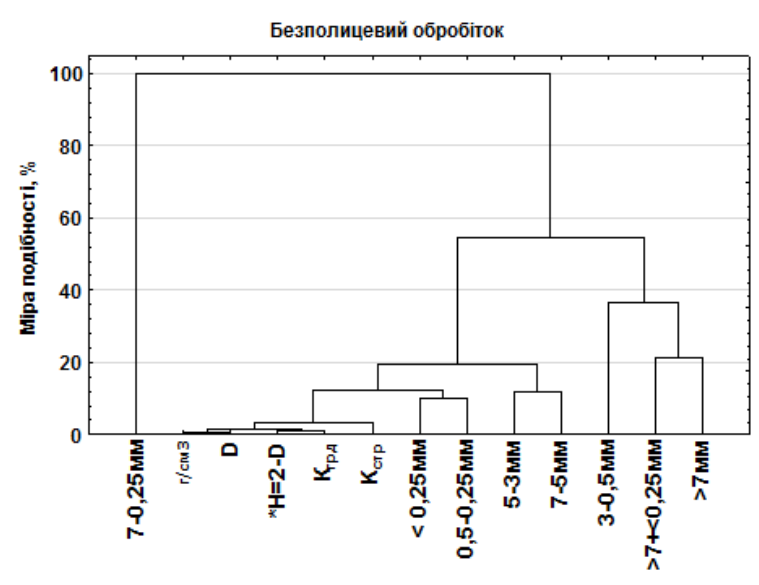

B

Fig. 2. Clustering of constituents of the structural state of black soil of agrogenic loading: plowing (A) and fieldless cultivation (B)

The results of the clustering of chernozems of different types of treatment by cluster analysis according to the distribution in them of structural individuals showed that the levels of similarity between the constituents and indicators of the assessment of the structural state of chernozems are low, which testifies to the reliability of the selected clusters. The cluster of calculated structural state indicators has the least degree of similarity - at $<10 \%$, while the components of the structural composition exhibit similarity at higher levels. Separate fractions of size $<0.25 \mathrm{~mm}$ and $0.5-0.25 \mathrm{~mm}$ have a similarity ratio of $10-12 \%$ and form a common cluster with estimated values of $15 \%$. The $7-5 \mathrm{~mm}$ fraction subordinates the previous cluster at $18 \%$, and the 5-3 mm fraction subordinates the two previous clusters at $25 \%$ (Fig. 2).

A separate cluster at the similarity level of $30 \%$ presents invaluable aggregates that obey fractions of structural individuals $3-0.5 \mathrm{~mm}$ at the similarity level> $50 \%$. Further clustering at the $55 \%$ similarity level is subordinated to a cluster subordinate to the $5-3 \mathrm{~mm}$ fraction, and the 7-0.5 $\mathrm{mm}$ fraction determines the clustering at the highest level.

The clustering of these indices while holding the fracture and the virgin soil showed that, under natural conditions, the most valuable groups of structural individuals $(7-0.5 \mathrm{~mm}$ and $3-0.5 \mathrm{~mm})$ are subject to the less valuable fractions: $>7 \mathrm{~mm}, 7-5 \mathrm{~mm}, 0.5-0.25 \mathrm{~mm}$ and $<0.25 \mathrm{~mm}$ in increasing degree of similarity: 10 , $20,60,100 \%$, which is fundamentally different from clustering in cultivated chernozem. The use of ashless cultivation contributes to the manifestation of clustering in the direction of holding the remnants and the virgin soil (Fig. 2).

In the general analysis, a strong inverse correlation $\left(R=-0.71-0.74 \pm 0.02 ; R^{2}=0.50-0.55\right)$, and between the fractions of individual sizes $>7 \mathrm{~mm}$ and the invaluable aggregates, the bond was straightforward at the level of strong correlation. In a systematic plowing condition, the correlation of the density of the structure with the agronomically valuable aggregates decreases to a weak inverse correlation $(R=-0.25-0.32 \pm 0.02)$. A direct correlation is established with the contents of structural entities $<0.25 \mathrm{~mm}$ in size. By systematic plowing, the correlation relationship between the density of the structure and the agronomically valuable 
aggregates decreases to a weak inverse correlation $(R=-0.35-0.32 \pm 0.02)$. A direct correlation is established with the contents of structural entities $<0.25 \mathrm{~mm}$ in size.

The systematic implementation of shelf-free tillage enhances the inverse correlation of the density of the structure with the content of the individual agronomically valuable interval to the average level $(R=-0.53-$ $0,65 \pm 0.02)$. A direct correlation between the density of the structure and the invaluable groups of aggregates is established at the average level: $R=0.24-0.48 \pm 0.02$.

What is important is that the role of fraction fraction of $7-0.5 \mathrm{~mm}$ in the decomposition of black soil increases with the non-polishing treatment. The process of loosening for shelfless cultivation is similar to loosening in the retention of the fold and the virgin soil and is determined by the growth of the content of structural units of $3-0.5 \mathrm{~mm}$ in size, which are more than $5-10 \%$ relative to plowing for non-shelf cultivation, and the proportion of sizes $7-0.5 \mathrm{~mm}$ exceeds $55-60 \%$.

According to the general model, $0.01 \mathrm{~g} / \mathrm{cm}^{3}$ reduced the density of the structure, $0.57-0.68 \%$ increase in the content of structural units of 3-0.5, $5-3$ and $7-0.5 \mathrm{~mm}$. In the case of shelf-free processing of $0.01 \mathrm{~g} / \mathrm{cm}^{3}$, the structure density was reduced by $0.57-0.61 \%$ of the mentioned agronomically valuable units, while for plowing the role of agronomically valuable structural units is at a low functional level, and the compaction is determined by agronomically invaluable structural units.

2. The regression equation between the structural coefficient $(y)$ and the content of structural individuals $(x)$ of different size in different methods of cultivation of black soil

\begin{tabular}{|c|c|c|c|c|}
\hline \multirow{2}{*}{$\begin{array}{c}\text { Size of } \\
\text { structural units, } \\
\mathrm{mm}\end{array}$} & \multirow{2}{*}{$\begin{array}{l}\text { Regression equation, } \\
\qquad y=a \pm b x\end{array}$} & \multicolumn{2}{|c|}{ Odds: } & \multirow{2}{*}{$\begin{array}{l}\text { The reliability of the } \\
\text { regression equation, } p\end{array}$} \\
\hline & & $\begin{array}{c}\text { Correlations, } \\
\mathrm{R}\end{array}$ & $\begin{array}{c}\text { determination, } \\
\mathrm{R}^{2}\end{array}$ & \\
\hline \multicolumn{5}{|c|}{ Plowing } \\
\hline $7-5$ & $y=10,5+0,041^{*} x$ & $+0,35$ & 0,15 & 0,95 \\
\hline $5-3$ & $y=6,44+3,80^{*} x$ & $+0,78$ & 0,61 & 0,0081 \\
\hline $3-0,5$ & $y=27,3+3,02^{*} x$ & $+0,68$ & 0,46 & 0,031 \\
\hline $7-0,25$ & $y=48,9+7,61^{*} x$ & $+0,94$ & 0,88 & 0,00004 \\
\hline$<0,25$ & $y=4,98+0,47^{*} x$ & $-0,23$ & 0,05 & 0,631 \\
\hline$>7+<0,25$ & $y=51,2-7,60^{*} x$ & $-0,94$ & 0,88 & 0,0004 \\
\hline \multicolumn{5}{|c|}{ Off-the-shelf processing } \\
\hline $7-5$ & $y=6,91+2,47^{*} x$ & $+0,62$ & 0,38 & 0,0005 \\
\hline $5-3$ & $y=10,9+1,88^{*} x$ & $+0,65$ & 0,45 & 0,015 \\
\hline $3-0,5$ & $y=24,5+3,75^{*} x$ & $+0,87$ & 0,76 & 0,0001 \\
\hline $7-0,25$ & $y=45,0+9,62^{*} x$ & $+0,98$ & 0,96 & 0,0001 \\
\hline$<0,25$ & $y=7,95-0,87^{*} x$ & $-0,25$ & 0,06 & 0,045 \\
\hline$>7+<0,25$ & $y=54,7-9,58^{*} x$ & $-0,98$ & 0,96 & 0,0001 \\
\hline
\end{tabular}

A systematic plowing between the structural coefficients (Kstr) and the content of agronomically valuable aggregates $(7-0.25 \mathrm{~mm})$ revealed a direct correlation dependence, and with fractions $5-3 \mathrm{~mm}$ and 3-0.5 mm the relationship was at a lower functional level : $R=0.67-0.78 \pm 0.02 ; R^{2}=0.45$. In the case of shelf-free cultivation, the functional dependence between the OCT and agronomically valuable aggregates increases, especially with the fraction of structural units of size $3-0.5 \mathrm{~mm}: R=0.86 \pm 0.02 ; R^{2}=0.74$, which is more effective (1.65 times) with respect to plowing (Table 2).

Statistical evaluation of the structural state of the chernozems under consideration showed that the average content of agronomically valuable aggregates $(7-0.25 \mathrm{~mm}$ ) was $67.7 \%$, and by the median $-64.6 \%$. The amplitude span (max-min) ranged from 52.4 to $93.4 \%$ for the standard normalized span of $59.8-74.6 \%$, and for the $10 \%$ confidence level $-55.4-83.1 \%$ for the coefficient of variation $16.3 \%$ (Table 3 ).

3. Statistical parameters of the structural composition of the black soil of the agrogenic loading of the left-bank Forest Steppe

\begin{tabular}{|c|c|c|c|c|c|c|c|}
\hline \multirow{4}{*}{$\begin{array}{l}\text { Agrophysi } \\
\text { cal state } \\
\text { parameters }\end{array}$} & \multicolumn{6}{|c|}{ Content of structural units, \%: } & \multirow{4}{*}{ 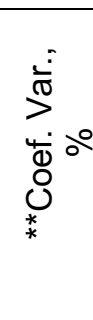 } \\
\hline & \multirow{3}{*}{$\begin{array}{l}\frac{0}{8} \\
\frac{\pi}{0} \\
\frac{\pi}{\alpha}\end{array}$} & \multirow{3}{*}{$\begin{array}{l}\frac{c}{0} \\
\frac{\pi}{0} \\
\frac{0}{2}\end{array}$} & \multicolumn{2}{|c|}{$\begin{array}{l}\text { Amplitude range } \\
(\Delta=\text { max-min): }\end{array}$} & \multicolumn{2}{|c|}{$\begin{array}{c}\text { Normalized span } \\
\Delta=L 0.75-0.25\end{array}$} & \\
\hline & & & $\min$ & $\max$ & ${ }^{*} \mathrm{~L}_{0,25}$ & ${ }^{*} \mathrm{~L}_{0,75}$ & \\
\hline & & & \multicolumn{2}{|c|}{$\Delta=\max -\min$} & \multicolumn{2}{|c|}{$\Delta=\mathrm{L}_{0,75}-\mathrm{L}_{0,25}$} & \\
\hline
\end{tabular}




\begin{tabular}{|c|c|c|c|c|c|c|c|}
\hline $7-5$ & 11,9 & 11,3 & 8,20 & 16,2 & 9,80 & 14,4 & 22,5 \\
\hline $3-0,5$ & 32,1 & 31,0 & 25,2 & 40,2 & 29,6 & 33,6 & 11,9 \\
\hline $7-0,25$ & 64,3 & 61,0 & 53,6 & 79,4 & 57,6 & 72,7 & 13,5 \\
\hline$>7+<0,25$ & 35,5 & 39,0 & 46,4 & 20,6 & 26,6 & 42,4 & 24,4 \\
\hline $\mathrm{K}_{\text {стр }}$ & 2,01 & 1,56 & 1,17 & 3,86 & 1,36 & 2,73 & 44,4 \\
\hline $\mathrm{K}_{\text {грп }}$ & 0,48 & 0,44 & 0,22 & 0,81 & 0,30 & 0,64 & 41,4 \\
\hline $\mathrm{g} / \mathrm{cm}^{3}$ & 1,18 & 1,18 & 1,12 & 1,25 & 1,15 & 1,20 & 2,85 \\
\hline \multicolumn{7}{|c|}{ Plowing } \\
\hline $7-5$ & 10,5 & 9,75 & 8,60 & 15,7 & 9,30 & 11,6 & 19,9 \\
\hline $3-0,5$ & 33,5 & 34,3 & 23,6 & 39,4 & 31,0 & 36,3 & 14,5 \\
\hline $7-0,25$ & 64,4 & 63,0 & 52,4 & 83,1 & 59,6 & 70,1 & 13,7 \\
\hline$>7+<0,25$ & 35,6 & 37,0 & 47,6 & 16,9 & 29,9 & 40,2 & 24,7 \\
\hline $\mathrm{K}_{\text {стр }}$ & 2,05 & 1,71 & 1,10 & 4,92 & 1,55 & 2,35 & 53,3 \\
\hline $\mathrm{K}_{\text {грп }}$ & 0,49 & 0,45 & 0,14 & 0,85 & 0,31 & 0,63 & 44,7 \\
\hline $\mathrm{g} / \mathrm{cm}^{3}$ & 1,16 & 1,15 & 1,09 & 1,25 & 1,13 & 1,19 & 4,74 \\
\hline
\end{tabular}

The fraction of the most valuable individuals $(3-0.5 \mathrm{~mm})$ was $35.1 \%$ for the amplitude and normalized span of $23.6-51.0 \%$ and $30.6-39.7 \%$, respectively, and for the $10 \%$ probability level $-29.1-43.0 \%$ for the coefficient of variation $18.3 \%$. Structural separations of $5-3$ and $7-5 \mathrm{~mm}$ in size were 23 and $16 \%$ on average and $21.4-24.4 \%$ and $15.5-16.0 \%$, respectively, at the interval coefficient of variation of 29.4 and $22.7 \%$.

On average, sizes $>7 \mathrm{~mm}$ contained $25.4 \%$ with a standardized range of $15.5-35.9 \%$ with a coefficient of variation of $48.3 \%$. On the whole, agronomically invaluable structural units averaged $32.3 \%$ with a typed range of $40.1-25.4 \%$ with a coefficient of variation of $33.9 \%$. The calculation of the ratio of fractions of structural individuals in the size of 7-5 mm to $5-3 \mathrm{~mm}$ to $3-0.5 \mathrm{~mm}$ and $7-0.25 \mathrm{~mm}$ for the content of chernozems in the state of fracture and virgin soil was 1 to 2.25 to 4.61 to 8,6 , and for the general model -1 to 1.45 to 3.25 to 6.3 .

For systematic plowing -1 to 1.35 to 3.2 to 6.1 , and for unmanned tillage -1 to 1.23 to 2.7 to 5.3 . The average content of coarse-grained structural units $(>7 \mathrm{~mm})$ in the case of translucent retention $-8.4 \%$, in the general model $-25.4 \%$, and for plowing and unpolished cultivation $-29.6-29.7 \%$. The typical normalized range was $5.6-13.3,15.5-35.9,26.5-32.0$ and $22.6-35.0 \%$ for coefficients of variation of $54,48.3,19.9$ and $22.5 \%$.

In the structural individual fraction, the ratio of components ( $>7 \mathrm{~mm}$ to $<0.25 \mathrm{~mm}$ ) was 0.85 to 1 - shift state, 3.7 to 1 - the general model, 5 to $1-$ for plowing and 4.5 to $1-$ for unmanned processing. It should be acknowledged that the indicator fraction of structural entities is more $>7 \mathrm{~mm}$ apart in both average and median and interval typical values. The average content of agronomically invaluable aggregates for the general model was $32.3 \%$ for interval values from 40.1 to $25.4 \%$ with a coefficient of variation of $34.9 \%$, for cultivated black earths $-35.5-35.6 \%$ for interval values from $40.2-42.4 \%$ to 26.6 to $29.9 \%$ by coefficients of variation of $24.4-24.7 \%$. For comparison: for the content of chernozems in the state of the fold and the virgin soil $-18.3,13.5-26.1 \%$ for the coefficient of variation $41.3 \%$.

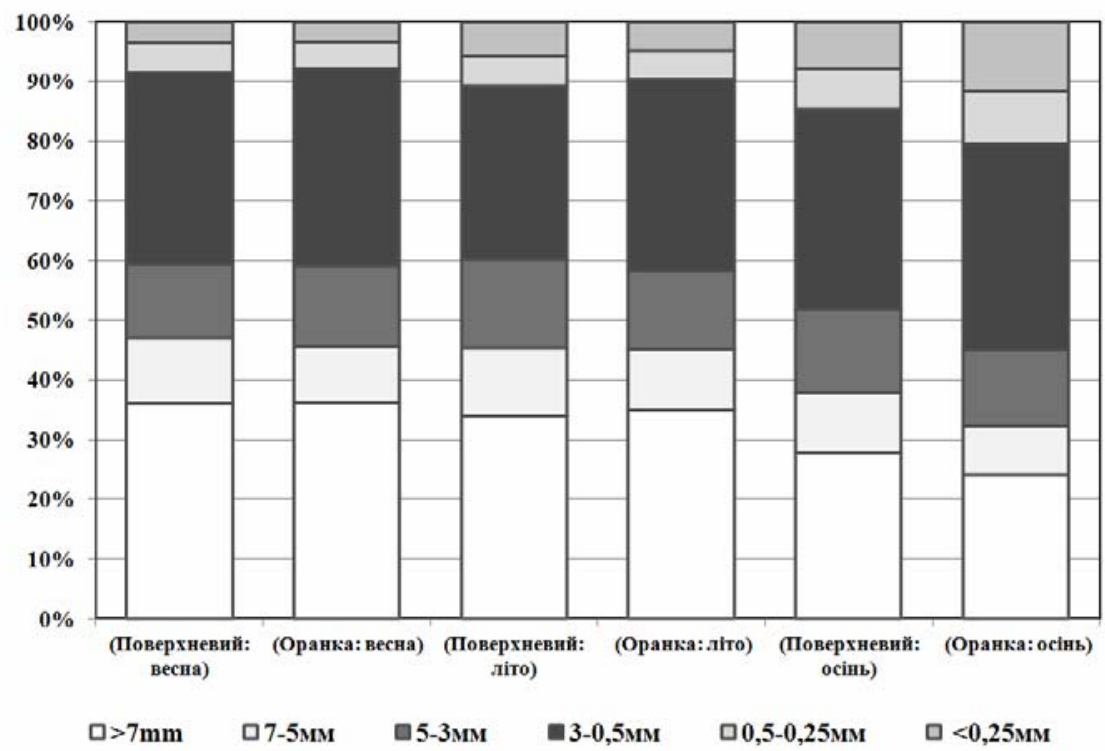

Fig. 4. Dynamics of the structural state of the chernozem in the implementation of different methods of cultivation in grain-tilled 5-saw crop rotation 
The dynamics of the structural state of the black soil in the soil layer $0-30 \mathrm{~cm}$ in different methods of cultivation has certain features, which are manifested in the fact that in the spring there is no significant difference in the structural state (Fig. 4). In the summer, systematic plowing increases by $2.8-3.0 \%$ of the individual size of $3-0.5 \mathrm{~mm}$, and in the field without tillage by $1.7-2.0 \%$ and $1.5-2.0 \%$ of the content of sizes $5-3 \mathrm{~mm}$ and $7-5 \mathrm{~mm}(3.0-4.0 \%$ in total) with equivalent plowing growth of agronomically invaluable structural units.

At the end of the growing season (September), the plowing content increases by $0.5-0.25 \mathrm{~mm}$ and $<0.25$ $\mathrm{mm}$ to $8.0-9.0 \%$ and $>10 \mathrm{~mm}$ at the same time, with a slight decrease in the number of individual units $>7.0$ $\mathrm{mm}$. During the fieldless tillage in the autumn period the number of individual units grows in size $>7 \mathrm{~mm}$ and there is a slight, but less than in the plowing, growth of the contents of the individual areas $3-0.5 \mathrm{~mm}$.

The number of fragments was $0.5-0.25 \mathrm{~mm}$ and $<0.25 \mathrm{~mm}$ was 1.28 and 1.5 times smaller, respectively, compared to plowing. The total number of structural units with a size of 7-3 $\mathrm{mm}$ for non-shelf cultivation remained at the level of spring content, while for plowing it decreased by 1.15-1.2 times, ie, the size of $>7$ $\mathrm{mm}$ and $7-5 \mathrm{~mm}$ for non-shelf cultivation is stable reserve for replenishment of the most valuable fractions of 3-5 $\mathrm{mm}$ and 3-0.5 $\mathrm{mm}$, while during plowing the pattern of the structure is revealed less pronounced and more related to the dispersion of the black earth structure. In the structural individual fraction, the ratio of components ( $>7 \mathrm{~mm}$ to $<0.25 \mathrm{~mm}$ ) was 0.85 to 1 - shift state, 3.7 to 1 - the general model, 5 to $1-$ for plowing and 4.5 to $1-$ for unmanned processing. It should be acknowledged that the indicator fraction of structural entities is more $>7 \mathrm{~mm}$ apart in both average and median and interval typical values. The average content of agronomically invaluable aggregates for the general model was $32.3 \%$ for interval values from 40.1 to $25.4 \%$ with a coefficient of variation of $34.9 \%$, for cultivated black earths $-35.5-35.6 \%$ for interval values from $40.2-42.4 \%$ to 26.6 to $29.9 \%$ by coefficients of variation of $24.4-24.7 \%$. For comparison: for the content of chernozems in the state of the fold and the virgin soil $-18.3,13.5-26.1 \%$ for the coefficient of variation $41.3 \%$.

\section{Conclusions}

Strengthening of the agrogenic and technogenic load on the Black Forest of the forest-steppe is to a greater extent the formation of fractions of structural separate $>7 \mathrm{~mm}$, and to a lesser extent $<0.25 \mathrm{~mm}$, and decreases the amount of the most valuable in the agronomic sense of the fraction $3.0-0.5 \mathrm{~mm}$. With systematic plowing, this process is pronounced, and the use of shelf-free tillage contributes to the restoration of the soil structure and the formation of intermediate fractions of 7-5 $\mathrm{mm}$ and 5-3 $\mathrm{mm}$ and a steady increase in the number of individuals 3-0.5 $\mathrm{mm}$.

The size fraction of 10-7 $\mathrm{mm}$ is an important characteristic fraction of the structural state of cultivated chernozem of the forest-steppe, according to which it is possible to determine the orientation of the structure formation of chernozems in agrocenoses under the influence of agrogenic loading. A general pattern is revealed, the essence of which is that, regardless of the state of the soil, the proportion of 3-0.5 mm separately in the amount of agronomically valuable $(7-0.25 \mathrm{~mm})$ individuals, regardless of their number, is $51-54 \%$, and the gain agrogenic load accelerates the formation of the coarse-grained fraction (> $7 \mathrm{~mm}$ ) by up to $30 \%$, agronomically invaluable parts up to $35.6 \%$, and the particle size $<0.25 \mathrm{~mm}$ accounts for $6-10 \%$.

The application of shelf-free tillage begins on the agrotechnical backgrounds of long-term plowing, where a significant number (> 35\%) of large-grouped structural units $(>7 \mathrm{~mm}$ ) and $<0.25 \mathrm{~mm}$ units are formed. Under its influence, the destruction of large clumps of fractions occurs with a gradual increase in the number of more valuable fractions (7-5 $\mathrm{mm}$ and 5-3 $\mathrm{mm}$ ), which leads to a slight increase in the density of the soil layer 0-30 cm in the first 3-5 years. Loosening begins when the content of the fragments 5-3 $\mathrm{mm}$ increases with the further consolidation of the soil structure around the formation of structural fragments of 3-0.5 mm in size, which subordinates the reduction of the contents of the fragments to $<0.25 \mathrm{~mm}$.

\section{References}

1. Medvedev, V. V. (2016). Ahrozem yak nove 4-vymirne polihenne utvorennia [Agrozem as a new 4dimensional polygenic formation]. Pedology, 17(1-2), 5-20. doi: 10.15421/04160. [In Ukrainian].

2. Mamontov, V. G., Babeiko, R. F., Lazarev, V. I., Yudin, S. A., Tsvetkov, S. A., \& Teller, E. B. (2019). Izmenenie strukturnogo sostoyaniya chernozema tipichnogo Kurskoy oblasti pod vliyaniem bessmennogo para i ozimoy pshenitsy [Changing the structural state of the chernozem typical of the Kursk region under. the influence of steaming steam and winter wheat]. Agriculture, 1, 7-9. doi: 10.24411/ 0044-3913-201910102. [In Russian].

3. Kuznetsova, I. V., Utkaeva, V. F., \& Bondarev, A. G. (2014). Normativy izmeneniya fizicheskikh svoystv pakhotnykh chernozemov lesostepnoy zony Yevropeyskoy Rossii $v$ usloviyakh intensivnogo selskokhozyaystvennogo ispolzovaniya [Norms of change of physical properties of arable chernozems of 
forest-steppe zone of European Russia under conditions of intensive agricultural use]. Soil science, 1, 7181. [In Russian].

4. Medvedev, V. V., Plisko, V. V., \& Bigun, O. V. (2014). Sravnitelnaya kharakteristika optimalnykh i realnykh parametrov chernozemov Ukrainy [Comparative Characterization of Optimal and Real Parameters of Black Earths of Ukraine]. Soil science, 10, 1247-1261. [In Russian]. 10.

5. Bryk, M. (2004). Form indices of soil structure classification. Polish Journal of Soil Science, 37(1), 1-

6. Medvedev, V. V. (2013). Chasova ta prostorova heterohenizatsii ornykh gruntiv [Temporal and spatial heterogeneization of arable soils]. Pedology, 14(1-2), 6-22.

7. Cheverdin, Yu. I. (2008). Dlitelnost raspashki i fizicheskoe sostoyanie chernozemov Kamennoy Stepi [Duration of plowing and physical condition of the Black Steppe Steppe]. Agriculture, 3, 28-30. [In Russian].

8. Bryk, M., Slowinska-Jurkewicz, A., \& Kolodziej, B. (2004). Wplyw systemy uprawy on zawartosc wengla organicznego w glebie. Ann. UMCS.E, 59(1), 345-352.

9. Norn, R., \& Fleige, H. (2000). Prediction of mechanical strength and ecological properties of subsoils for a sustainable landuse. Proc. of the workshop "Experiences with the impact of subsoil compaction". (pp. 109-121). Uppsala. Sweden.

10. Slowinska-Jurkewicz, A., Kolodziej, B., \& Bryk, M. (2004). Wplyw zabiegow agrotecnicznych on the structure of gleby pylowey - assessment of morphometryczna macroporow. Ann. UMCS.E, 59(1), 329-335.

11. Medvedev, V. V. (2010). Nulovyi obrobitok gruntu v Yevropeiskykh krainakh [Zero tillage in European countries]. Kharkov: Eden. [In Ukrainian].

12. Medvedev, V. V. (1990). Izmenchivost optimalnoy plotnosti pochv i ee prichiny [Variability of optimal soil density and its cause]. Soil science, 5, 20-31. [In Russian].

13. Bondarev, A. G. (2007). O znachenii fizicheskikh svoystv pochv v adaptivno-landshaftnom zemledelii [On the value of soil physical properties in adaptive - landscape agriculture]. Bulletin of the Soil Institute named after V. V. Dokuchaev, 60, 71-74. [In Russian].

14. Medvedev, V. V. (2011). Fizicheskie svoystva i glubina zaleganiya pluzhnoy podoshvy $v$ raznykh tipakh pochv [Physical properties and depth of plow sole in different soil types]. Soil science, 11, 1487-1495. [In Russian].

15. Medvedev, V. V. (1998). Optimizatsiya agrofizicheskikh svoystv chernozemov [Optimization of agrophysical properties of chernozems]. Moscow: Agropromizdat. [In Russian].

16. Kornishchuk, V. V., \& Egorova, T. M. (2018). Ahroekolohichne raionuvannia Ukrainy [Agro-ecological zoning of Ukraine]. Agro-ecological journal, 4, 6-22. doi: 10.33730 / 2077-4893.4.2018.155744. [In Ukrainian].

17. Panasenko, O. S. (2012). Humus strukturnykh okremostei chornozemiv typovykh riznykh ekosystem [The humus of the structural features of the chernozem typical of different ecosystems]. Bulletin of Kharkiv National Agricultural University, 4, 93-98. [In Ukrainian].

18. Moses, K. G., Boytsova, L. V., \& Goncharov, V. D. (2014). Analiz dinamiki gumusnogo sostoyaniya pochv fraktalnymi metodami [Analysis of soil humus dynamics by fractal methods]. Agrophysics, 1(13), 1-8. [In Russian].

19. Kiselev, B. V. (2007). Ob interpretatsii statisticheskogo R-S-analiza (Pokazatel Khersta) [On the interpretation of statistical R-S analysis (Hirst indicator)]. Questions of Agrophysics (Scientific Notes of Saint Petersburg State University), 40, 121-130. [In Russian].

20. Kholodov, V. A., Yaroslavtseva, N. V., Lazarev, V. I., \& Fried, A. S. (2016). Interpretatsiya dannykh agregatnogo sostava tipichnykh chernozemov raznogo vida ispolzovaniya metodami klasternogo analiza i glavnykh komponent [Interpretation of data of aggregate composition of typical chernozems of different types of use by methods of cluster analysis and principal components]. Soil science, 9, 1093-1100. doi: 10.7868/S0032180X16090070. [In Russian]. 